\title{
Effect of rainfall infiltration on the hydraulic response and failure mechanisms of sandy slope models
}

\author{
Efecto de la infiltración de lluvia en la respuesta hidráulica y en \\ los mecanismos de falla de modelos de taludes arenosos
}

\author{
Efeito da infiltração de chuva na resposta hidráulica e nos \\ mecanismos de falha de modelos de taludes arenosos
}

Fecha de recepción: 5 de abril de 2016

Fecha de aprobación: 1 de junio de 2016

\author{
Juan David Montoya-Domínguez \\ Edwin Fabián García-Aristizábal* \\ Carlos Alberto Vega-Posada
}

\begin{abstract}
This paper presents experimental results obtained from silty sand slope models subjected to an artificial rainfall. Four models were constructed to evaluate the effect of initial water content and rainfall intensity on the hydraulic behavior and failure mechanisms of the slopes. The models were instrumented with volumetric water content sensors to monitor the advance of the water front, and inclinometers to measure lateral movements of the slope. The models were subjected to rainfall intensities ranging from 25 to $50 \mathrm{~mm} / \mathrm{h}$, and durations from 19 to 152 minutes. The influence of low intensity rainfall events before a high intensity rainfall is discussed herein. The results showed that the time the slope models required to reach failure was influenced by the soil initial water content; being shorter at high initial water contents. These results are useful to understand the behavior of unsaturated natural slopes and embankments exposed to rainfall infiltration, and to complement the existing laboratory database existing in this subject.
\end{abstract}

Keywords: initial water content; laboratory testing; slope models; unsaturated soil; water infiltration.

\section{Resumen}

Presenta los resultados experimentales obtenidos en modelos de taludes arenosos sometidos a lluvia. Se construyeron cuatro modelos para evaluar el efecto del contenido inicial de agua y de la intensidad de la lluvia en

\footnotetext{
* $\quad$ M. Sc. Geomecánica Integral S.A.S. (Medellín-Antioquia, Colombia).

** Ph.D. Universidad de Antioquia UdeA, (Medellín - Antioquia, Colombia). edwin.garcia@udea.edu.co.

*** Ph.D. Universidad de Antioquia UdeA, (Medellín-Antioquia, Colombia). carlosa.vega@udea.edu.co.
} 
el comportamiento hidráulico y el mecanismo de falla en los taludes. Estos modelos fueron instrumentados con sensores de contenido volumétrico de agua, para monitorear el avance del frente húmedo y con inclinómetros para medir los movimientos laterales de talud. Los modelos fueron sometidos a intensidades de lluvia y duraciones que se encontraron entre 25 y $50 \mathrm{~mm} / \mathrm{h}$ y 19 y 152 minutos, respectivamente. Adicionalmente, se discutió el efecto de un evento de lluvia de baja intensidad previo a una lluvia de alta intensidad. De los resultados, se observa que el tiempo requerido para alcanzar la falla del talud está influenciado por el contenido inicial de agua; siendo más corto el tiempo para contenidos de agua iniciales más altos. Los resultados presentados son útiles para entender el comportamiento de los taludes naturales y terraplenes parcialmente saturados y expuestos a infiltración de lluvias; así como para complementar la base de datos existente en este tema.

Palabras clave: contenido inicial de agua; ensayos de laboratorio; infiltración de agua; modelos de talud; suelo parcialmente saturado.

\section{Resumo}

Apresentam-se os resultados experimentais obtidos em modelos de taludes arenosos submetidos à chuva. Construíram-se quatro modelos para avaliar o efeito do conteúdo inicial de água e da intensidade da chuva no comportamento hidráulico e o mecanismo de falha nos taludes. Estes modelos foram instrumentados com sensores de conteúdo volumétrico de água, para monitorar o avanço da frente úmida e com inclinômetros para medir os movimentos laterais de talude. Os modelos foram submetidos a intensidades de chuva e durações que se encontraram entre 25 e $50 \mathrm{~mm} / \mathrm{h}$ e 19 e 152 minutos, respectivamente. Adicionalmente, discutiu-se o efeito de um evento de chuva de baixa intensidade prévio a uma chuva de alta intensidade. Dos resultados, observa-se que o tempo requerido para alcançar a falha do talude está influenciado pelo conteúdo inicial de água; sendo mais curto o tempo para conteúdos de água iniciais mais altos. Os resultados apresentados são úteis para entender o comportamento dos taludes naturais e aterros parcialmente saturados e expostos a infiltração de chuvas; assim como para complementar a base de dados existente neste tema.

Palavras chave: conteúdo inicial de água; ensaios de laboratório; infiltração de água; modelos de talude; solo parcialmente saturado. 


\section{INTRODUCTION}

Among natural hazards, landslides occur virtually anywhere in the world. Although they are attributed to many factors, it is widely recognized that rainfall infiltration is the main trigger of slope instability. Landslides triggered by rainfall are shallow in nature [1], and can occur during a heavy rainfall or immediately after it [2]. They usually occur on slopes that are marginally stable and involve different types of unsaturated soils such as colluvial and residual soils [3-4]. The study of rainfall-induced landslides is an important topic of interest in geotechnical research due to its negative effects on natural slopes and embankments [5-9], and because these types of failures are frequently severe, resulting in damages to facilities and loss of human lives.

Understanding the nature of water movement throughout an unsaturated geomaterial has been a subject of interest to many disciplines and professionals such as hydrologist, geologist, soil scientists, geotechnical and environmental engineers, agriculture engineers, etc. It is also essential to understand a variety of problems related to runoff prediction due to heavy rainfall, sediment transport and flooding control, rainfall-induced landslides, estimation of aquifers recharge, estimation of water availability for plants, contaminants' travel velocity, etc.

The mechanisms of rainfall-induced landslides have been extensively documented worldwide [2, 4, 1015]. For instance, Johnson and Sitar [16] reported the results of pore water pressure measurements in a major debris flow source area of clayed silt located in Briones Hills, California. These results indicated that the soil layer reached saturation during the rainy season, and developed positive excess pore water pressures. Anderson and Sitar [2] observed that during heavy rainfalls, water infiltration near the surface increased the pore water pressure of the soil and induced failure of the slope. There is also evidence that a perched water table may accumulate above a soil-bedrock interface, or above a contact where the underlying layer has a significant lower hydraulic conductivity, causing the upper soil to become fully saturated, and inducing positive excess pore water pressures along the interface [17-18].

Chaminda [15], Eckersley [19] and Shimoma et al. [20] presented the results of slope model tests subjected to artificial rainfalls, and instrumented with pore pressure and moisture content sensors. They found that failure was initiated when the soil at the toe of the slope was fully saturated, and excess positive pore water pressure developed. Orense [3] explained how soil suction is reduced when rainwater infiltrates through the soil profile. The decrease in effective stress and reduction of the soil's strength leads the slope to a point where equilibrium cannot longer be sustained. Despite the great interest and considerable efforts made to study the problem of rainfall-induced landslides, the effect of water infiltration on natural and artificial slopes is not yet fully understood. Especially, there is still need for further experimental studies on infiltration processes to better understand the soil hydraulic properties and failure mechanisms associated with these processes.

Hormaza [21] and Saldarriaga [22] prepared an inventory of the most relevant disasters occurred in the Aburra Valley, Colombia, from 1880 to 1988, and from 1900 to 2002, respectively. The information for these inventories came from newspapers, and historical and technical documents. Later, by combining these two works, Aristizabal and Gómez [23] summarized the landslide incidents and precipitations occurred in the Aburra Valley from 1880 to 2007. They showed that $35 \%$ of the natural disasters corresponded to landsides triggered during rainfall peak periods (April - May and September - October), noting a direct relationship between rainfalls and landslides. This study also concluded that landslides caused more losses of life and damages than any other natural disaster, therefore, the importance of deepen our knowledge of the effect of infiltrated rainfall on sandy slopes.

In this work, a total of four sandy slope models were constructed and subjected to an artificial rainfall to evaluate the hydraulic behavior and failure mechanisms of the slopes. The influence of the initial water content and rainfall intensity on the slope behavior was investigated. The models were instrumented with moisture content sensors to monitor the advance of the water front, and inclinometers were used to record lateral movements along the slope during the application of the rainfall. This research aims to provide some insights into the physics of rainfall infiltration on unsaturated slopes and embankments exposed to rainfall infiltration. 


\section{TESTING AND PROGRAM PROCEDURE}

A laboratory experimental program was implemented to evaluate the hydraulic behavior and failure mechanisms of sandy slope models subjected to an artificial rainfall. A total of four sand models were built and instrumented with moisture content sensors and inclinometers for this purpose. A rectangular box of $70 \mathrm{~cm}$ in length, $40 \mathrm{~cm}$ in height, and $30 \mathrm{~cm}$ in width was assembled to prepare the slope models. The models were subjected to rainfall intensities and durations ranging from 25 to $50 \mathrm{~mm} / \mathrm{h}$, and 19 and 152 minutes, respectively.

\section{A. Material description}

The sand employed to construct the slope models, known as the Edosaki sand, was obtained from a natural slope in Japan. According to the Unified Soil Classification System (USCS), this sand is classified as a silty sand (SM). A typical grain size distribution curve and index properties of the Edosaki sand are presented in Figure 1.

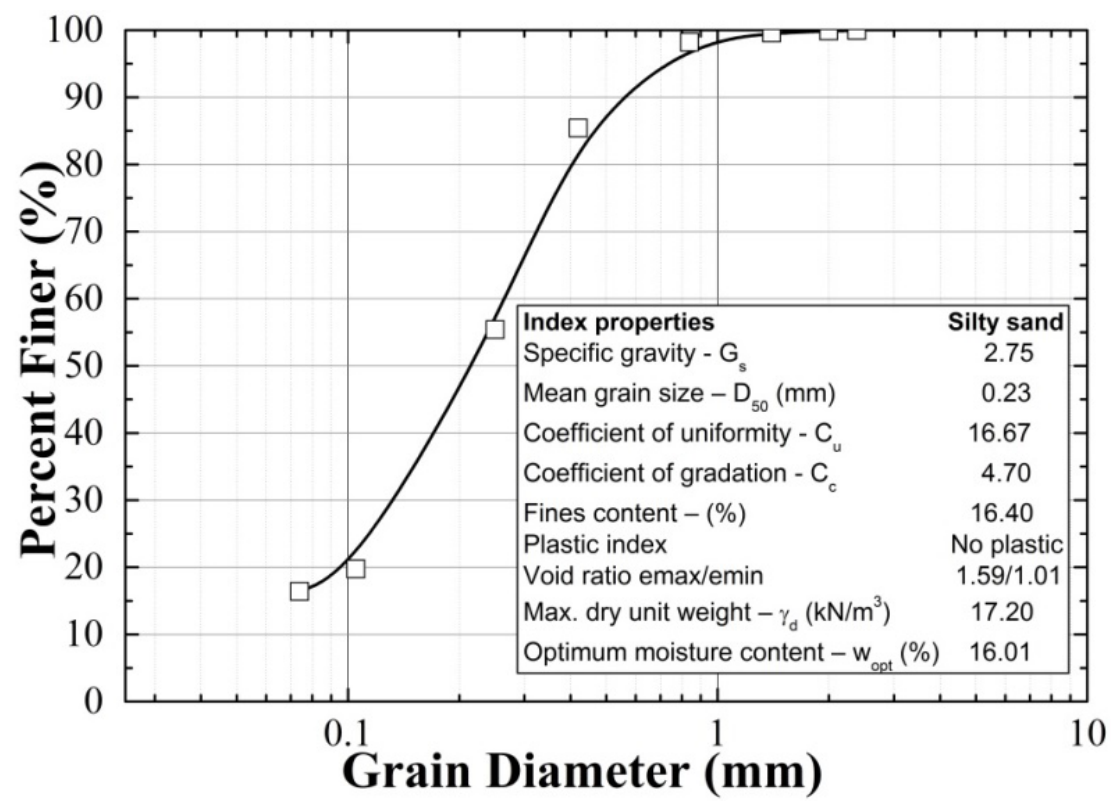

Fig. 1. Typical grain size distribution curve.

\section{B. Slope model and measurement system}

1) Slope box: Figure 2 shows a schematic diagram of the soil box, and the location of the water content sensors and inclinometers used to monitor the response of the embankment when subjected to the artificial rainfall. The walls of the soil box were made of wooden plates, except for the front side, which was made of transparent acrylic to facilitate the observation of the failure process. The joints were sealed with silicone to prevent any water leakage from happening. A rectangular grid was drawn on the acrylic wall to control the compaction process of the layers, and to observe the embankment's deformations during the water infiltration process. 


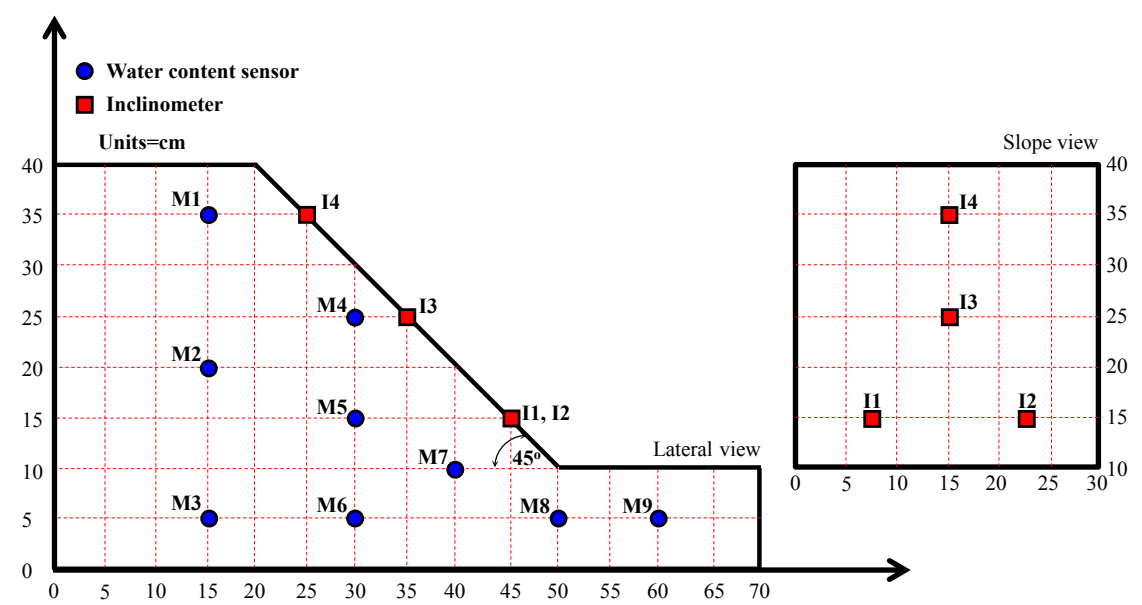

Fig. 2. Sketch of the longitudinal and transverse views of the models, and location of the water content sensors and inclinometers.

2) Measurement system: Volumetric water content (VWC) sensors were used to monitor changes in water content $\left(q_{v}\right)$ throughout the soil profile. Nine (9) ThetaProbe type ML2x transducers, developed by The Macaulay Land Use Research Institute and Delta-T Devices, were installed in the models at the locations illustrated in Figure 2. Figure 3a shows a picture of this device and its dimensions. Additionally, four (4) SCA100T-D01 inclinometers, fabricated by Murata Manufacturing Co., with a precision of 0.0001 degrees, were installed in the slope's surface at the places shown in Figure 2. A positive reading on this device indicates a rotation in a clockwise direction. The advantages of this inclinometer over conventional ones are that they are just simply placed in the point of interest, have a low temperature dependency, high resolution, low noise, low sensitivity to vibrations, and high sensitivity to the slope deformation. Figures $3 \mathrm{~b}$ and $3 \mathrm{c}$ show, respectively, the sensor electronic components before and after being covered with silicone for protection during testing.

The output signals from the sensors were sent to an analog to digital (A/D) converter and then to a data logger, where data sampling were recorded at a required frequency. The $\mathrm{A} / \mathrm{D}$ converts the voltage signals received as output from the volumetric water content sensors and inclinometers into a digital format that can be read by a computer.

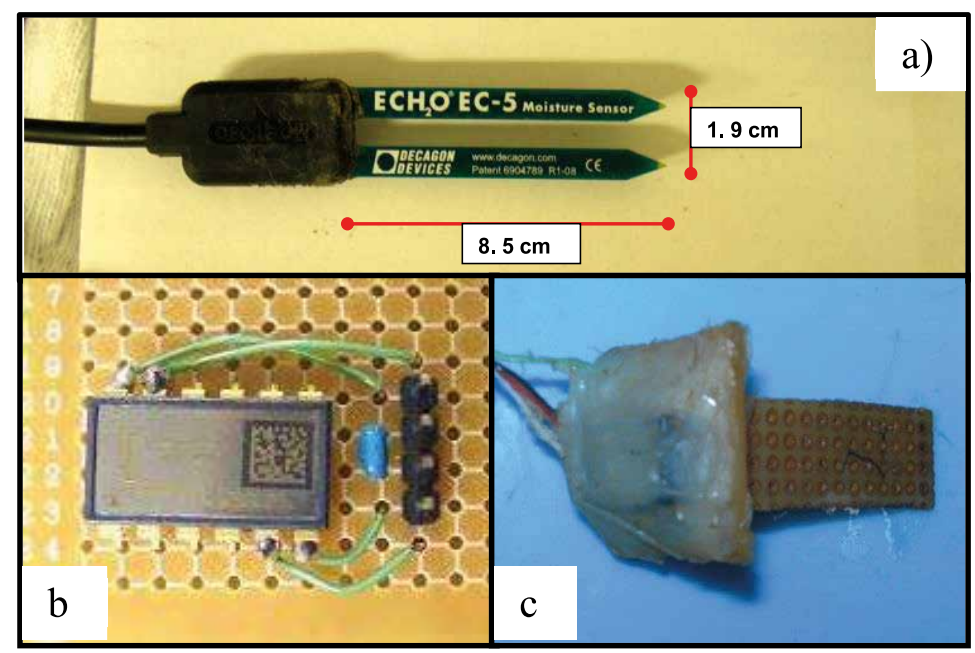

FIG. 3. a) Water content sensor, b) inclinometer electronic components, and c) inclinometer covered with silicone for protection during testing. 


\section{Testing program and model test preparation}

Four (4) slope model tests were constructed (Figure 2) and tested following the rainfall intensities and durations shown in Table 1. The models were compacted to a dry density of $12 \mathrm{kN} / \mathrm{m}^{3}$ and had initial water contents ranging from $5 \%$ to $36 \%$.

\section{TABLE 1}

SLOPE MODEL TEST PROGRAM

\begin{tabular}{|c|c|c|c|c|c|}
\hline Test & $\begin{array}{c}\text { IWC (\%) } \\
(*)\end{array}$ & $\begin{array}{c}\boldsymbol{\rho}_{\text {dry }} \\
\left(\mathbf{k N / m ^ { 3 } )}\right.\end{array}$ & $\begin{array}{c}\text { Slope Incl. } \\
(\mathbf{d e g r e e})\end{array}$ & $\begin{array}{c}\text { Rainf. Int. } \\
(\mathbf{m m} / \mathbf{h})\end{array}$ & $\begin{array}{c}\text { Duration } \\
(\mathbf{m i n})\end{array}$ \\
\hline SM-01 & $12-15$ & 12 & 45 & 50 & 21 \\
\hline SM-02 & $8-12$ & 12 & 45 & 25 & 152 \\
\hline SM-03 & $34-36$ & 12 & 45 & 50 & 15 \\
\hline SM-04 & $5-15$ & 12 & 45 & 50 & 90 \\
\hline
\end{tabular}

(*) Initial Water Content

The models were prepared using the wet tamping technique. This sampling technique consists on placing the wet soil in multiple layers and compact each layer with a tamper to achieve the target density. A summary of the construction procedure is described as follows:

- A $1 \mathrm{~cm}$-thick layer of gravel is placed at the bottom of the soil box to facilitate the drainage process (Figure 4a), and then, it is covered with a nonwoven geotextile to protect the granular material against contamination by fine particles.

- The silty sand was mixed with the target initial water content and then deposited on multiple 5 $\mathrm{cm}$-thick layers. After compaction, each sublayer matched the corresponding horizontal reference mark, ensuring a dry density of $12 \mathrm{kN} / \mathrm{m}^{3}$. Figure $4 \mathrm{~b}$ shows a picture of the tamping procedure implemented to construct the models.

- Volumetric water content sensors were installed within the model at the locations shown in Figure 2. To place a sensor, a trench a few centimeters deep was excavated, and then the sensor inserted into the compacted soil (Figure 4c).

- After completion of the slope model, the inclinometers were placed in the surface at the locations shown in Figure 2. After that, the model was allowed to stabilize for a period of time between 12 and 18 hours, before initiating the rainfall infiltration process. Figures $4 \mathrm{~d}$ and $4 \mathrm{e}$ show a lateral and frontal view, respectively, of the instrumented slope model and the experimental setup.
- Wooden markers were installed at different locations of the slope model, following a predetermined arrangement, to monitor the superficial and lateral deformation of the slope models. Surface markers were made of $2 \times 2 \mathrm{~cm}$ rectangular wooden pieces and fixed to the soil by using $3 \mathrm{~cm}$ long nails. Lateral markers consisted of cylindrical wooden pieces of $1.5 \mathrm{~cm}$ in diameter and embedded $2.5 \mathrm{~cm}$ into the soil. In both cases, the exposed surface of the wooden pieces was painted in white with a small black dot at the center to trace each marker displacement during the testing process, and to record them for image analysis.

- A sprinkler connected to the water supply and placed $1 \mathrm{~m}$ above the slope's model surface was used as the rainfall simulator system. The rainfall intensity was controlled by adjusting a water pressure regulator located between the water supply and the sprinkler. Rainfall was applied as homogeneously as possible on an area of approximately $1.5 \mathrm{~m}^{2}$ (Figure 5).

- Rainfall was measured by using a rain gauge. Cumulative rainfall was recorded at different time intervals during the testing procedure, and the rainfall intensity was calculated as the gradient of the cumulative rainfall versus time. Typical rainfall intensities were between 25 and $50 \mathrm{~mm} / \mathrm{h}$, suggesting that most of the models experienced heavy rain. 

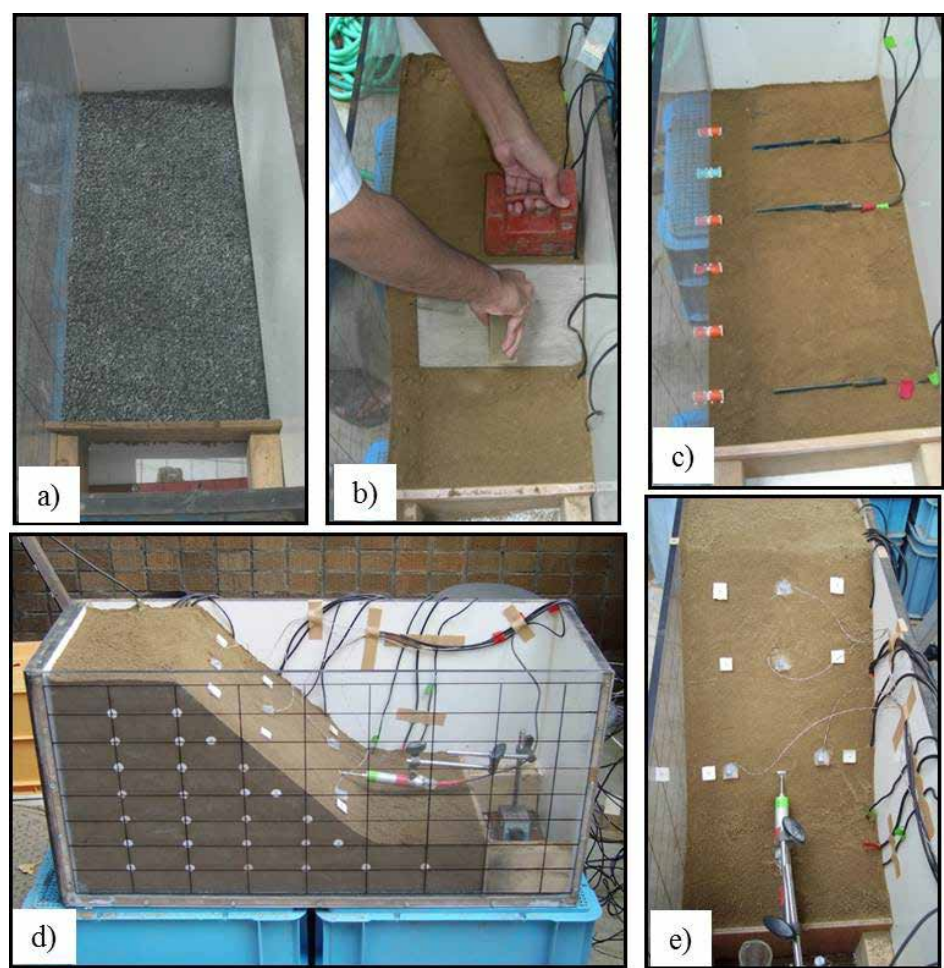

Fig. 4. a) Gravel layer at the bottom, b) placement and compaction of the material, c) installation of the VWC sensors, d) lateral view, and d) front view of the completed model.

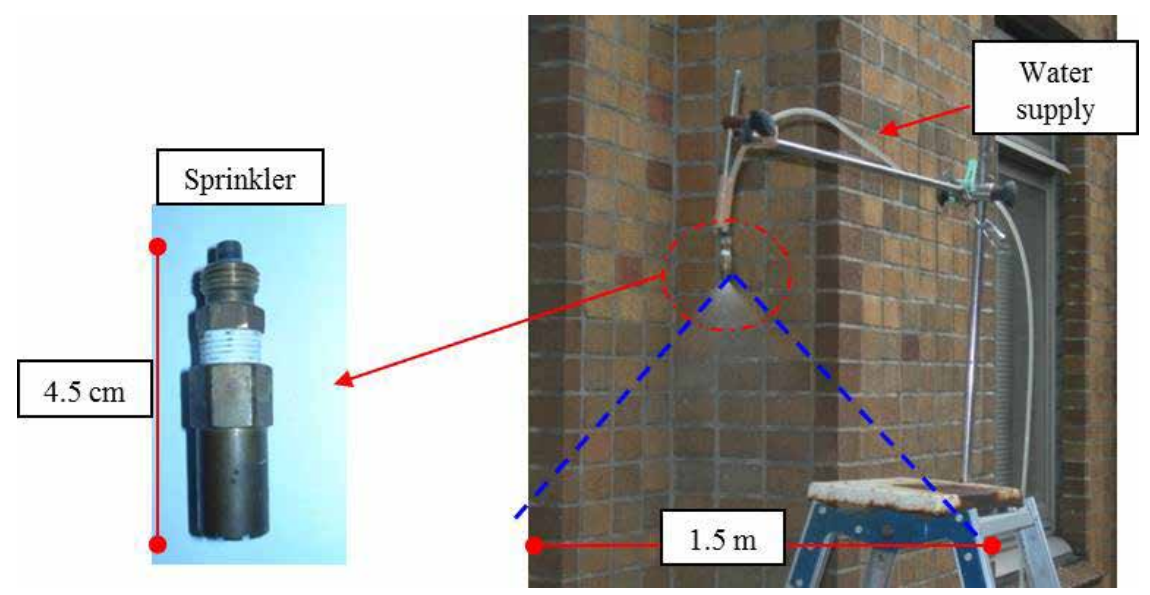

Fig. 5. Sprinkler used as rainfall simulator.

\section{EXPERIMENTAL RESULTS AND DISCUSSION}

The hydrological response of the four (4) slope models subjected to an artificial rainfall and the failure mechanisms observed on their slopes were analyzed by interpreting the data recorded by the inclinometers and VWC sensors installed near the surface (M1, M4, M7, and M9). The data recorded by the other
VWC sensors are not shown herein because their interpretation is beyond the scope of the present work. Rainfall intensity and initial water content played an important role in the behavior of the slope models during the rainfall event. The results are presented as follows: 


\section{A. Slope Model SM-01}

Slope model test SM-01 was prepared with IWCs ranging from $12 \%$ to $15 \%$, and subjected to an artificial rainfall intensity of $50 \mathrm{~mm} / \mathrm{h}$ during 21 minutes. Figure 6 shows the VWC readings from sensors M1, M4, M7 and $\mathrm{M} 9$, and inclination responses recorded during the rainfall application.

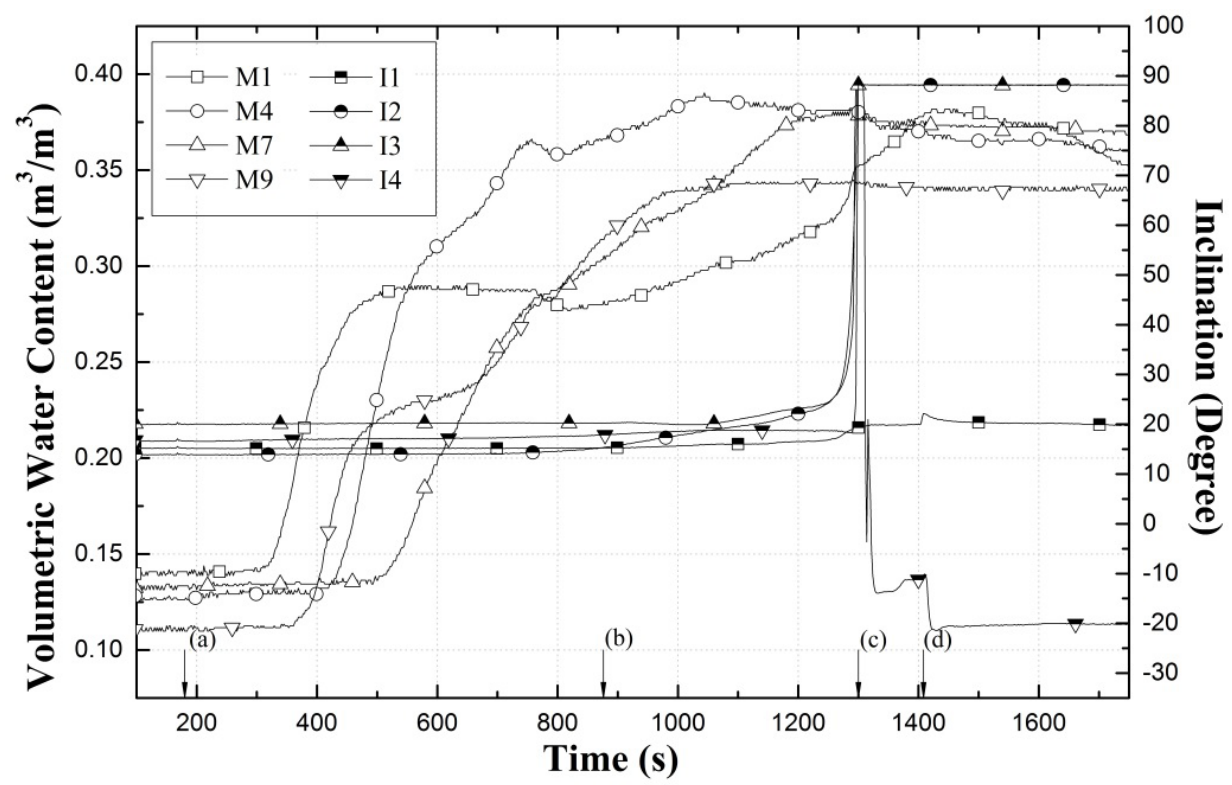

(a) Rainfall starts, $180 \mathrm{~s}$. (b) Deformation at the toe starts and a surface crack appears at the top, $880 \mathrm{~s}$. (c) Slope fails, 1300 s. (d) Rain ends, $1440 \mathrm{~s}$.

Fig. 6. Moisture content and inclination measurements of model SM-01.

In Figure 6, the VWC sensors showed an increase in water content at the surface soon after rainfall infiltration started. After approximately 700 seconds of water infiltration $(\mathrm{t}=880 \mathrm{~s})$, an outward deformation was observed at the toe of the slope, and a superficial crack appeared at the top of the model. Finally, when the moisture content of the slope was around $34 \%$ and $37 \%$ (sensor M9), the slope reached saturation and failure occurred. During failure, inclinometers I2 and I3 moved in a clockwise direction, I4 in a counterclockwise direction, and I1 remained almost constant, indicating a shallow rotational failure that involved only the right side of the model. This response agreed well with the one observed in the model (Figure 7). 


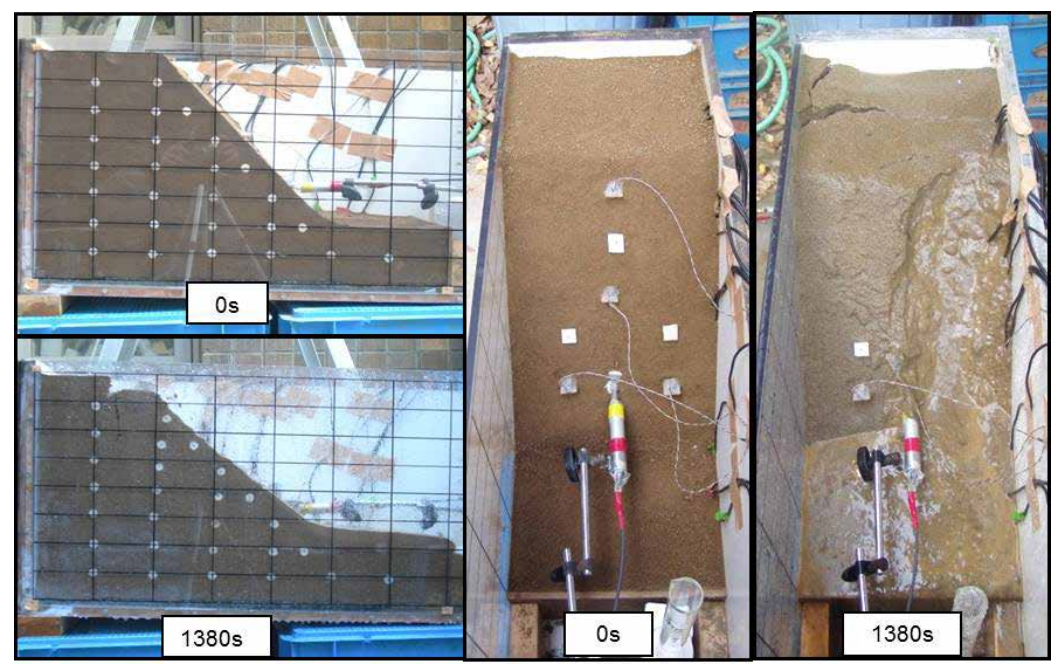

Fig. 7. Lateral and front views of model SM-01. Deformations after 0 and 1380 seconds after rainfall initiation.

\section{B. Slope Model SM-02}

Slope model test SM-02 was prepared with IWCs ranging from $8 \%$ to $12 \%$, and subjected to a rainfall intensity of $25 \mathrm{~mm} / \mathrm{h}$ during $152 \mathrm{~min}$. Figure 8 shows the VWC and inclinometer readings during water infiltration. The water front reached sensors M1 and M9 and sensors M4 and M7 at approximately 2000 and $3000 \mathrm{~s}$, respectively, after rainfall initiation. At approximately $3500 \mathrm{~s}$, the inclinometers moved simultaneously, suggesting that deformation took place at the same time along the slope's surface. At approximately $5000 \mathrm{~s}$, the deformation at the toe of the slope stopped (inclinometers I1 and I2), but it continued moving in a counterclockwise direction at the slope and crest (inclinometers I3 and I4). Finally, after $9120 \mathrm{~s}$ of rainfall, failure was not achieved and the test stopped, allowed to dry, and tested again 24 hours later (slope model SM-03).

Although the toe of the slope reached saturation as in the previous test, failure did not occur after 151 minutes of continuous rainfall application. Additionally, runoff was not observed during the test, suggesting that failure was not reached as consequence of the low rainfall intensity.

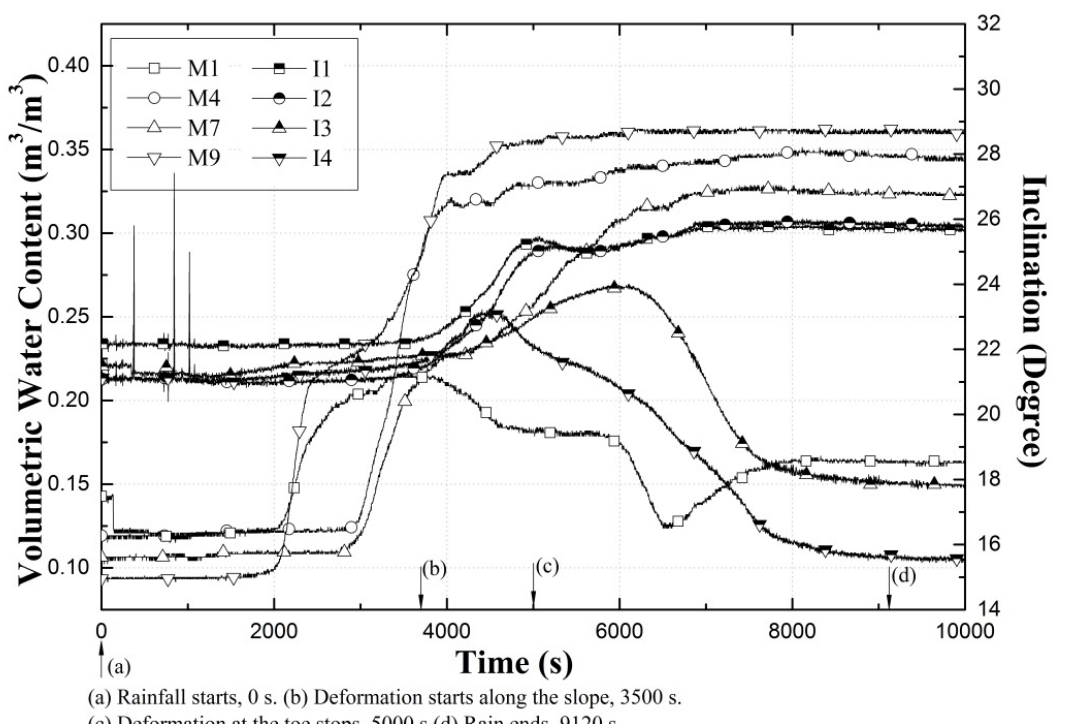

(a) Rainfall starts, 0 s. (b) Deformation starts along the slope, 3500

Fig. 8. Moisture content and inclination measurements of model SM-02. 


\section{Slope Model SM-03}

Slope model test SM-03 consisted on applying a higher rainfall intensity to model test SM-02, which did not fail under a low intensity rainfall of $25 \mathrm{~mm} / \mathrm{h}$ and a duration of $152 \mathrm{~min}$. Model SM-02 was allowed to dry for 24 hours and then was subjected to a rainfall intensity of $50 \mathrm{~mm} / \mathrm{h}$ during 15 minutes. The aim of this experiment was to observe the response of the slope model to increments in rainfall intensity after a prolonged period of low rainfall intensity. Figure 9 shows the VWC and inclinometer responses of this test. It can be observed that volumetric water contents remained above $35 \%$ as consequence of the previous rainfall application in SM-02. Additionally, the deformation of the slope was first registered by inclinometer $\mathrm{I} 2$ at approximately $250 \mathrm{~s}$ after rainfall started, and then followed by inclinometers I1, I3 and I4 until failure occurred at $750 \mathrm{~s}$ (Figure 9). Inclinometers I1, I2, and I4 moved in a counterclockwise direction, and I3 in a clockwise direction indicating a translational failure of the slope.
The results obtained in models SM- 02 and SM- 03 show the importance of previous rainfall events in the initiation of slope instability. In model SM-02, low intensity rainfall caused an increase in volumetric water content within the soil, but not enough to trigger a global instability of the slope. Low intensity rainfalls generate a gradual growth of the water level inside the slopes, increasing the soil pore pressure (reduction of suction) and, therefore, reducing the shear strength of the soil. Subsequently, model SM03, which was subjected to a higher rainfall intensity in a shorter period of time than that of model SM-02, experienced a rapid saturation of the surface due to the high initial volumetric water content, leading to a rapid slope failure. Rahardjo et al. [24] showed, through numerical modeling, that different rainfall patterns applied on a slope generate different porewater pressure responses within the soil. They used this information to calculate the safety factors of the slope, and to highlight the important role of antecedent rainfalls on slope stability.

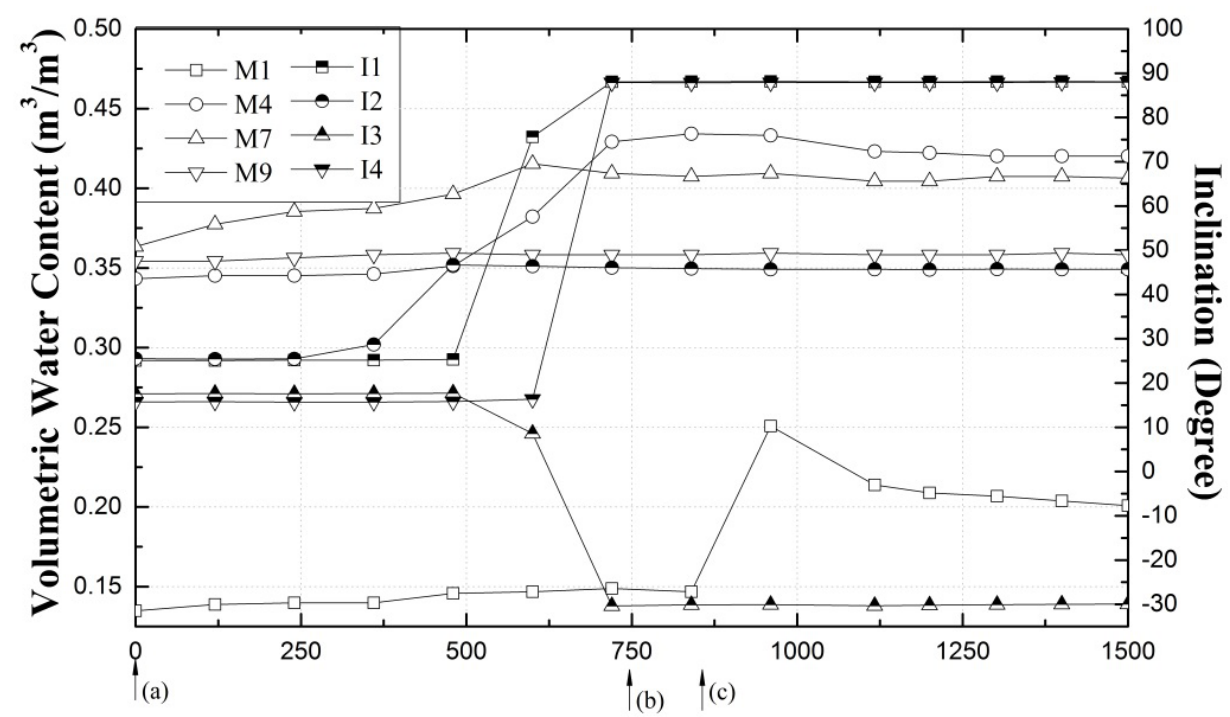

(a) Rainfall starts, 0 s. (b) Slope fails, 750 s. (c) Rain ends, 900 s.

Fig. 9. Moisture content and inclination measurements of model SM-03.

\section{Slope Model SM-04}

Finally, slope model test SM-04 was performed with IWCs ranging between $5 \%$ and $15 \%$, and then was subjected to a rainfall intensity of $50 \mathrm{~mm} / \mathrm{h}$ during 90 minutes. Figure 10 presents the response of the VWC sensors and inclinometers. 


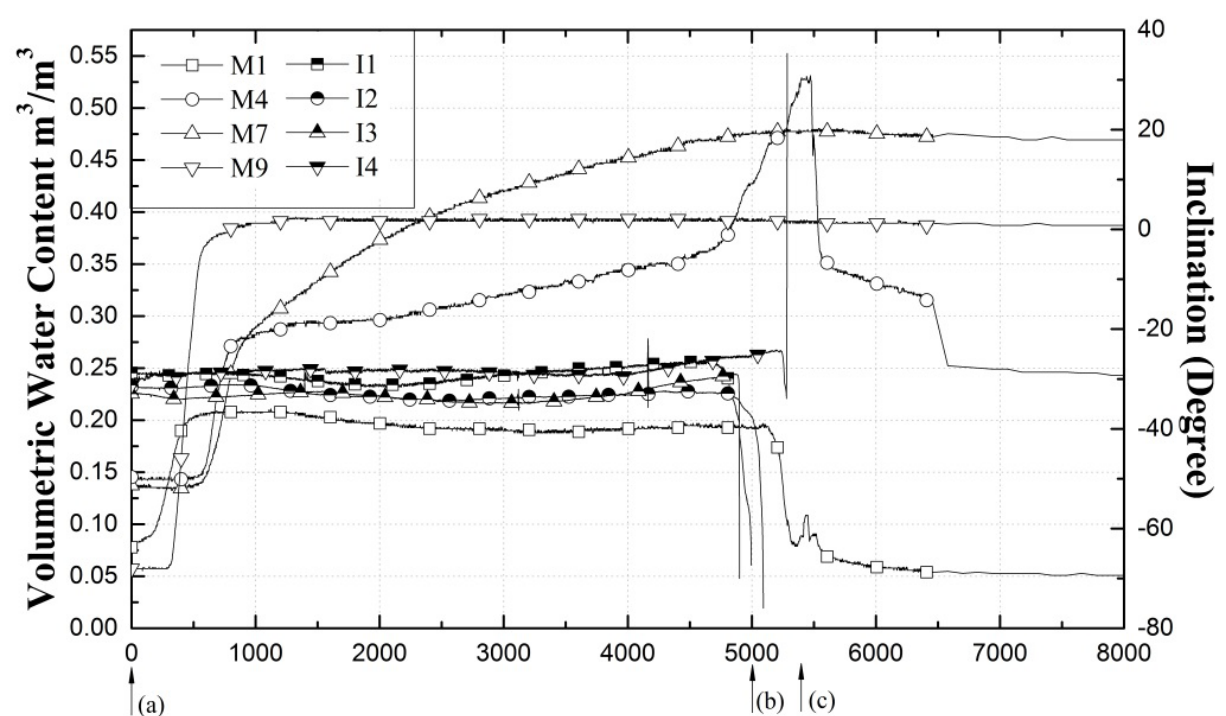

(a) Rainfall starts, 0 s. (b) Deformation at the toe starts and slope fails, 5000 s. (c) Rain ends, $5400 \mathrm{~s}$.

Fig. 10. Moisture content and inclination measurements of model SM-04.

In this test, the inclinometers registered a slight deformation of the slope's surface during the rainfall event. This deformation started to significantly increase at approximately $5000 \mathrm{~s}$ and continued until failure occurred. Failure was registered at the same time by the inclinometers, indicating that the response was similar to the responses recorded for tests SM01 and SM-03, where a sudden failure of the whole mass occurred. The results from this model suggest that failure started at the toe of the slope due to the high VWC of the soil at this point, and contributed to the development of an unstable area. Finally, as water continued infiltrating into the slope, the failure became a plane failure, making the soil mass to slide.

Observations made from slope models SM-01, SM-03 and SM-04 are useful to understand the influence of initial water content on the failure mechanisms. In that sense, it can be noted how slope models SM-04, SM01 and SM-03 required approximately $5000 \mathrm{~s}, 1300 \mathrm{~s}$ and $700 \mathrm{~s}$, respectively, before failure occurred. Initial water contents for those tests were between $5 \%$ and $15 \%$ for SM- $04,12 \%$ and $15 \%$ for SM- 01 , and $34 \%$ and $36 \%$ for SM-03 (Table 1). These results indicate that less rainfall-infiltrated time is required to reach failure as the initial water content of the soil increases.

\section{Conclusions}

The hydrological behavior and failure mechanisms of slope models exposed to an artificial rainfall were studied by constructing four slope model tests, and subjected them to high rainfall intensities. The models were built with different initial water contents to evaluate its influence on soil behavior. In addition, the slope models were instrumented with volumetric water content sensors and inclinometers at different locations. The results provide some insights into the response of silty sand slopes during a rainfall infiltration process; hence the following conclusions are drawn:

Rainfall intensity significantly influences the slope's deformation process, and the time required to increase the volumetric water content of the slope.

The initial water content of the slope model was an important factor controlling the time for failure and the failure mechanism itself. As observed from tests SM-04, SM-01 and SM-03, failure required less time as the average initial water content of the slope increased: SM-04, $5000 \mathrm{~s}$; SM-01, $1300 \mathrm{~s}$; and SM03, $750 \mathrm{~s}$.

Models SM-02 and SM-03 showed that low intensity rainfall can induce limited deformations on the slopes, but they may not be enough to cause failure. However, 
water infiltrated during a low intensity event increase the volumetric water content of the soil, reducing its shear strength, and the slope could fail in a short period of time during a high intensity rainfall event.

The analyses of failure mechanisms on slope models subjected to artificial rainfall conducted from volumetric water contents and deformation responses agreed well with the observations of failure recorded during the tests. Measurements of soil displacements within the tested models were directly related to the volumetric water content of the soil. Consequently, it could be possible to predict local and global failure in slopes by monitoring volumetric water contents and/ or deformations within the soil.

\section{REFERENCES}

[1] L. W. Abramson, T. S. Lee, S. Sharma, and G. M. Boyce. Slope Stability and Stabilization Methods. New York: Wiley Interscience Publications, 2001.

[2] S. A. Anderson and N. Sitar, "Analysis of rainfall-induced debris flows," $J$ Geotech Engrg, vol. 121(7), pp. 544-552, Jul. 1995. DOI: http://dx.doi.org/10.1061/(ASCE)07339410(1995)121:7(544).

[3] R. P. Orense. Geotechnical Hazards: Nature, Assessment and Mitigation. Quezon City: The University of the Philippines Press, 2003.

[4] M. R. Hakro and I. S. H. Harahap, "Laboratory experiments on rainfall-induced flowslide from pore pressure and moisture content measurements," Natural Hazards and Earth System Sciences, vol. 3, pp. 15751613, 2015. DOI: http://dx.doi.org/10.5194/ nhessd-3-1575-2015.

[5] Y. Yoshida, J. Kuwano, and R. Kuwano, "Raininduced slope failures caused by reduction in soil strength," Soils and Foundations, vol. 31(4), pp. 187-193, 1991. DOI: http://dx.doi. org/10.3208/sandf1972.31.4_187.

[6] H. Yamagishi, T. Horimatsu, T. Kanno, and M. Hatamoto, "Recent landslides in Niigata Region, Japan," in Proc. of the 4th Asian Symposium on Engineering Geology and the Environment, Hong Kong, 2004, pp. 1- 6.

[7] Y. Nakata, D. Liu, M. Hyodo, N. Yoshimoto, and Y. Kato, "Numerical simulation of an expressway embankment slope failure," in Proc. of Theoretical and Numerical Advances in Unsaturated Soil Mechanics, 2010, pp. 719724.

[8] H. Chen, S. Dadson, and Y. Chi, "Recent rainfall induced landslides and debris flow in northern Taiwan," Geomorphology, vol. 77(12), pp. 112-125, Jul. 2006. DOI: http://dx.doi. org/10.1016/j.geomorph.2006.01.002.

[9] S. W. C. Au, "Rain-induced slope instability in Hong Kong," Engineering Geology, vol. 51 (1), pp. 1-36, Nov. 1998. DOI: http://dx.doi. org/10.1016/S0013-7952(98)00038-6.

[10] E. W. Brand, "Some thoughts on rain-induced slope failures," in Proc. of the $10^{\text {th }}$ International Conference on Soil Mechanics and Foundation Engineering, vol. 3, 1981, pp. 373-376.

[11] E. W. Brand, "Analysis and design in residual soils," In Engineering and Construction in Tropical and Residual Soils, Proceedings of the ASCE Geotechnical Division Specialty Conference, Honolulu, Hawaii, 1982, pp. 89143.

[12] R. P. Brenner, H. K. Tam, and E. W. Brand, "Field stress path simulation of rain-induced slope failure," in Proceedings of the $11^{\text {th }}$ International Conference on Soil Mechanics and Foundation Engineering, vol. 2, 1985, pp. 991-996.

[13] J. H. Atkinson and D. M. Farrar, "Stress path tests to measure soil strength parameters for shallow landslips," in Proceedings of the $11^{\text {th }}$ International Conference on Soil Mechanics and Foundation Engineering, A. A. Balkema, Brookfield, Vt., vol. 2, 1985, pp. 983-986.

[14] K. Farooq, "Experimental Study on Failure Initiation in Sandy Slopes due to Rainfall Infiltration". Ph. D. dissertation, University of Tokyo, Japan. 2002.

[15] G. P. K. Chaminda, "Real Time Prediction of Rain-Induced Embankment by Minimum Measurements with Back-analysis for SWCC Parameters". Ph. D. Dissertation, University of Tokyo, Japan, 2006.

[16] K. A. Johnson and N. Sitar, "Hydrologic Conditions leading to debris-flow initiation," Canadian Geotechnical Journal, vol. 27(6), pp. 789-801, Dec. 1990. DOI: http://dx.doi. org/10.1139/t90-092.

[17] R. H. Campbell, "Soil slips, debris flows and rainstorms in the Santa Monica Mountains and vicinity," Southern California. U.S. Geological Survey Professional Paper 851, 1975, 51 pp. 
[18] P. Boonsinsuk and R. N. Yong, "Analysis of Hong Kong residual soil slopes," Engineering and Construction in Tropical and Residual Soils, Proc. ASCE Geotechnical Division Specialty Conference, Honolulu, Hawaii, 1982, pp. 463-482.

[19] J. D. Eckersley, "Instrumented laboratory flowslides," Géotechnique, vol. 40(3), pp. 489502, Sep. 1990. DOI: http://dx.doi.org/10.1680/ geot.1990.40.3.489.

[20] S. Shimoma, R. P. Orense, T. Honda, K. Maeda, and I. Towhata, "Model tests on slope failures caused by heavy rainfall," in Proc. Interpraevent 2002 in the Pacifica Rim: Protection of Habitat against Floods, Debris Flows and Avalanches, vol. 2, 2002, pp., 547-557.

[21] M. Hormaza, "Investigación preliminar de las causas probables de deslizamientos en las laderas de Medellín". Undergraduate dissertation, Universidad Nacional de Colombia, 529 pp., 1991.

[22] R. Saldarriaga, "Inventario y sistematización de los desastres naturales reportados en los municipios del Valle de Aburrá, entre los años 1900 y 2002". Undergraduate Dissertation, Universidad EAFIT, 120 pp., 2003.

[23] E. Aristizábal and J. Gómez, "Inventario de emergencias y desastres en el Valle de Aburrá: originados por fenómenos naturales y antrópicos en el periodo 1880-2007," Revista Gestión y Ambiente, vol. 10(2), pp. 17-30, 2007.

[24] H. Rahardjo, X. W. Li, D. G. Toll, and E. C. Leong, "The effect of antecedent rainfall on slope stability," Geotechnical and Geological Engineering, Springer, vol. 19, pp. 371-399, 2001. DOI: http://dx.doi. org/10.1023/A:1013129725263. 